\title{
A BAN ON AN EX-SPOUSE'S CONTACT WITH A MINOR CHILD IN THE PRESENCE OF THIRD PARTIES. CONSIDERATIONS FROM THE PERSPECTIVE OF FAMILY CASE-LAW
}

\section{Introduction}

The family is a basic social unit. This is where the initial stage of social assimilation occurs. The family is the first environment in which a child feels closeness, understanding, and love; where children's demands are met and their personality is shaped. The family is also a social unit providing various emotional connections and social roles, ${ }^{1}$ which primarily include those of a wife and husband, a mother and father, a child, a brother, a sister, and other relatives as well. Each relationship is reflected in the quality of family life.

* Dr., University of Bialystok; e-mail: r.tanajewska@uwb.edu.pl, https:/ /orcid.org/ 0000-0002-5673-1852.

1 See: M. Badowska-Hodyr, Rodzice $i$ ich dzieci w przestrzeni penitencjarnej z perspektywy zasady indywidualizacji oraz procesu reintegracji społecznej, Probacja 2018, no. 1, p. 25-52; M. Łolik, Więź rodzinna jako dobro osobiste. Glosa do wyroku SN z dnia 10 lutego 2017 r., V CSK 291/16, Przegląd Sądowy 2018, no. 5, p. 99-109; E. Pachała, Prawo do ochrony życia rodzinnego w świetle orzecznictwa Trybunału Konstytucyjnego, Przegląd Prawniczy UW 2018, vol. 17, no. 1, p. 80-96; M. Szaro, Rodzina a poczucie sensu życia u osadzonych, Przegląd Więziennictwa Polskiego 2018, no. 98, p. 69-83; G. Tylec, Zadośćuczynienie za naruszenie dobra osobistego w postaci więzi rodzinnej. Uwagi na tle orzecznictwa Europejskiego Trybunału Praw Człowieka oraz orzecznictwa sądów polskich, Przegląd Sądowy 2018, no. 3, p. 7-22; P. Kroczek, Rodzina w polskim systemie prawnym we współczesnych okolicznościach życia, in: T. Borutka, T. Kornecki, P. Kroczek, Rodzina fundamentem społeczeństwa. Aspekt społeczno-prawny, Kraków 2017, p. 141-171; J. Bucińska, Rodzina w świetle prawa międzynarodowego, in: Meritum. Prawo rodzinne, ed. G. Jędrejek, Warszawa 2017, p. 1609-1666. 
Marriages have recently been on the decline. It seems that the institution of marriage has been experiencing a crisis of trust. Although we could, at this point, start to discuss whether it is the institution of marriage or rather the spouses facing this crisis, the more important issue is the increase in the number of divorces. In 2016, about 193,500 marriages were concluded, while the number of divorces amounted to 63,500 . In 2017, about 192,600 marriages were recorded, compared to 65,300 divorces. However, in 2018, about 192,400 marriages were concluded, while 62,800 divorces were effected. These numbers look completely different in the statistics concerning towns and villages. According to the data of the Central Statistics Office, in 2016, 114,600 marriages were concluded in cities, while about 45,900 were dissolved. In 2017, 114,300 marriages were concluded and about 46,800 dissolved. Finally, in 2018, 114,800 marriages were concluded and about 45,200 dissolved. However, in rural areas, in 2016, 78,800 marriages were concluded and about 16,700 dissolved. In $2017,78,200$ marriages were concluded while about 17,500 dissolved. In 2018, 77,600 marriages were concluded and about 16,700 dissolved. ${ }^{2}$ Does this mean that married couples have a better chance of being in a compatible relationship in rural areas? It would rather be too hasty to come to this conclusion. The analysis of the collected research material shows that marriages concluded in rural areas, apart from an apparently solid emotional bond, rely on the necessity of maintaining a common agricultural holding. Additionally, the system of farm transfer in exchange for a farmer's pension tightens up marital bonds even more, because such farms are usually jointly owned. Therefore, in the case of a disagreement between the spouses, the property they own and the marital property system play a strong role therein. In addition, there is the issue of "patrimony", love for the land and faithfulness to beliefs. Are spouses less faithful to their ideals in cities? Such a conclusion would also be unjust, as the current urban society is focused on professional development which, in turn, does not facilitate the establishment of strong bonds in a relationship.

As a consequence of a disagreement between spouses, a child's well-being can be threatened. Instead of being in the center of attention, children become part of a marital or post-marital skirmish. ${ }^{3}$ The purpose of this

2 Gtówny Urząd Statystyczny, Rocznik Demograficzny 2019, Warszawa 2019.

3 See. R. Ćwikowski, Udziat dzieci w mediacji okołorozwodowej w Polsce i wybranych państwach zachodnich, Probacja 2018, no. 1, p. 83-108. 
publication is to depict the legal situation of minor children with regard to the exercise of parental authority, with particular emphasis on parental visitation rights. This issue is considered important because of the increasing number of marriages with still minor children. Additionally, it is necessary to underline that the child's welfare, which should be a priority in any proceedings, is repeatedly violated by those responsible for his or her protection, namely the parents. According to the research thesis considered herein, minor children of the parties to divorce proceedings become an element of a litigation game, both for the duration of such proceedings and afterwards, until they reach the age of majority.

The research has been carried out herein based on a dogmatic, analytical and empirical method, as well as the analysis of the relevant case-law. The dogmatic method was applied to analyze the provisions of the Family and Guardianship Code in terms of activities necessary to determine the manner of the exercise of parental authority, with particular emphasis on establishing visitations. The analytical method was used to review scientific studies and the views of doctrine representatives on the subject. The analysis of jurisprudence was carried out on the basis of selected court dispute settlements in the field of civil law. The empirical research method was applied to analyze the resources collected from ten selected divorce proceedings conducted in the years 2017-2019, which expressly focused on the problem of arranging visitation rights between the parties' minor child and the parent.

\section{Divorce and parental authority}

According to Article 56 of the K.r.i.o., ${ }^{4}$ if there has been a complete and permanent breakdown of life between the spouses, any of the spouses may request that the marriage be terminated by divorce. However, despite the complete and enduring disintegration of the life, divorce is not admissible if it would harm the common good of the minor children of the spouses or if it would otherwise be contrary to the principles of social life. Nor shall divorce be admissible where requested by the spouse who is

4 Family and Guardianship Code of 25 February 1964, Journal of Laws of 2019, item 2086 (hereinafter referred to as K.r.i.o.). 
solely guilty of such decay, unless the other spouse consents to divorce or unless it is contrary to the principles of social life under the circumstances.

Next, according to Article 58(1) of the K.r.i.o., in a judgment pronouncing a divorce, the court decides on parental authority over the common minor child of both spouses and the relationship between the parents and the child, and decides the amount in which each of the spouses is obliged to bear the costs of living and raising the child. The Tribunal shall take into account the written agreement of the spouses on how to exercise parental authority and maintain contact with the child after the divorce, if it is in the best interests of the child. Siblings should be brought up together, unless the best interests of the child require otherwise.

The legislator has provided for a solution in the next paragraph, which allows to maintain parental authority also in the case of a disagreement. Namely, pursuant to $\S 1$ a thereof, the court is authorized to decide how to exercise parental authority jointly and maintain contact with the child after divorce, taking into account the right of the child to be brought up by both parents. By way of a decision, the court may entrust the exercise of parental authority to one of the parents, limiting the parental authority of the other to certain duties and powers in relation to the child, if it is in the best interest of the child. It is also worth pointing to $\S 1 \mathrm{~b}$ of the analyzed article, where the legislator authorizes the court not to rule on the maintenance of contact with the child at the unanimous request of both parties. In such a case, it is up to the parties to determine the dates and manner of contact on a daily basis. This solution optimizes the possibility of establishing positive relations between the child and the parents as well as between ex-spouses, who are able to reach an agreement about raising their child. However, as the relevant case-law repeatedly indicates, such a solution is only possible and feasible if former spouses do not hamper the exercise of one another's visitation rights.

The literature indicates that parental authority should be treated as an overriding concept. Therefore, the concepts of exercising parental authority and providing contact with a child should not be separated. ${ }^{5}$ This separation is for procedural reasons only, in order to ensure that the child has a right of access to a parent with whom he or she is not permanently

5 More: A. Gałkan-Halicka, Wtadza rodzicielska a rozwód, in: Wokót problematyki matżeństwa w aspekcie materialnym i procesowym, eds. J.M. Łukasiewicz, A.M. Arkuszewska, A. Kościółek, Torun 2017, p. 391-408. 
residing in a court of law. ${ }^{6}$ However, it is a complete mistake to treat these two concepts dichotomously. ${ }^{7}$ Even if parental authority remains limited, it is still exercised, only in a reduced range of powers. Consequently, it is important to underline that a divorce always becomes a reason for the parental authority to be established, which does not mean that it would be limited in relation to any parent. Any limitation of parental authority must be based on facts which affect the best interests of the minor child. Similarly, when pronouncing a divorce, a court may become convinced that parental authority should remain with one parent for the benefit of the child, and then may confer on the other parent, certain powers and duties which are also within the scope of parental authority. However, this does not mean that the court limits parental authority. It is then considered that by delegating specific responsibilities to one parent, it leaves the exercise of parental authority with the other parent. ${ }^{8}$

Analyzing the case-law on parental authority, a reference should be made to the Supreme Court's Judgment of 2 December 1957, ref. no 1 CR $1045 / 56,{ }^{9}$ where the Supreme Court states that

the properly understood good of the child and social interest, which, in accordance with Article 54 of the Code of Criminal Procedure, are the main prerequisites for entrusting parental authority over children to one of the parties, require them not only to provide the child with clothes and food, but at least equally care for his physical and mental health, assuring his proper personal development and preparation to social life.

Although issued more than six decades ago, this ruling remains valid. After all, spouses divorce each other, not their children. Therefore, the children's welfare should be their priority.

Subsequently, in the Supreme Court's decision of 12 September 1978, ref. no III CRN 158/78, ${ }^{10}$ The Supreme Court stated that

6 P. Pałka, Ustalenie sposobu kontaktowania się z dzieckiem w toku postępowania o rozwód, Przegląd Sądowy 2006, no. 2, p. 80-93.

7 P. Mostowik, Kontakty dziecka z rodzicami, krewnymi i bliskimi a władza rodzicielska, Przegląd Sądowy 2013, no. 3, p. 31.

8 J. Gajda, K. Pietrzykowski, in: Kodeks Rodzinny i Opiekuńczy. Komentarz, Warszawa 2020 [database Legalis], Art. 58, Nb 15.

9 OSNCK 1959 no. 3, item 76.

10 Legalis no. 21055. 
entrusting under Article 107 of the K.r.i.o. the exercise of parental authority to one parent, with a certain limitation of that authority to the other, does not exclude, under Article 109 of the K.r.i.o., the possibility of obliging also that parent who has been entrusted with the exercise of parental authority to carry out certain proceedings and control orders issued in this respect (Article 109(2)(1) of K.r.i.o.), if such orders prove necessary due to a threat to the child's well-being.

This ruling is extremely important because it indicates who the actual recipient of the obligations arising from parental authority is - the child. Therefore, a parent with full parental authority is not entitled to freely decide on matters concerning the child. He or she must first and foremost respect the child's best interests. In addition, if there are any concerns about the proper exercise of parental authority, the court may impose certain obligations relating to the custody of the child on either party.

Referring to the judgment of the Court of Appeal in Łódź of 10 May 2017, ref. no. I ACa 1436/16, ${ }^{11}$ it should be noted that the Court held that

the choice of the method of limiting the parental authority of the other parent with whom the child will not be permanently present requires reference to circumstances concerning the current life situation of the child of the parties and the related mutual relationship of the spouses, and then consideration thereupon to what extent the issue of the child's welfare justifies the need and allows - without fear of frequent conflicts - both divorced parents to jointly exercise their duties and powers in relation to the child who is in their parental authority.

In recent years, it has become more and more common for divorcees to conclude a specific type of a contract before divorce proceedings. The parties thereto conclude a special mutual agreement prior to filing a divorce petition, in which they establish the rules concerning parental authority and all its aspects, including the way in which contact is to be made. Such an agreement is then annexed to the divorce application as an expression of the parties' willingness to reach a mutually agreed position. According to our own research, out of ten divorce cases, only three managed to conclude such an agreement. Of the three agreements concluded, two concerned the provision of joint custody, which meant that minor children of the parties would spend a week with one parent and another with

11 Legalis no. 1636802. 
the other. In the remaining seven cases, there was a growing conflict over how to establish contacts or the amount of maintenance to be paid.

When analyzing these seven cases, it should be noted that in two cases, one party sought to deprive the other party of parental authority, and in five cases, the conflict concerned the frequency of meetings. In each of the seven cases, however, the parties could not agree on the amount of maintenance payable to minor children.

In six out of the ten analyzed cases, one of the parties committed marital infidelity, one relationship broke up because one of the spouses was working abroad, another one - due to one party's dependence, and yet another one - due to a difference in character. The aforementioned agreements were concluded in the cases where the reason for divorce was marital adultery, work abroad of one of the spouses, and a difference in character. In the other cases, the parties could not be reconciled either before the divorce case was brought or during the divorce proceedings. Mediation did not help either. These cases ended with a court ruling, which had to weigh the interests of the parties and, above all, of the minor children.

In one out of the ten cases, a party demanded a ban on the other party's contact with the child, and in five out of the ten divorce cases, one party demanded a ban on contact with the minor child in the presence of third parties - cohabiting partners.

\section{The contact and third parties}

According to the content of Article $113^{3}$ of the K.r.i.o., if the maintenance of parental contact with a child seriously endangers or violates the welfare of the child, the court will prohibit their maintenance. The problem in applying this regulation is the lack of a uniform definition of what child's welfare is and what a threat or violation of that welfare is. It seems that an accurate and still valid definition of child's welfare is the one formulated by Wanda Stojanowska, according to which

the welfare of a child is [...] a complex of intangible and tangible values which are necessary to ensure the proper physical and spiritual development of a child and provide him or her with appropriate preparation to work in accordance with his or her abilities. These values are affected by many different 
factors whose structure depends on the content of applicable legal norms and the specific situation of the child, which should be assumed as consistent with the public interest. ${ }^{12}$

Furthermore, trying to find an area where maintaining parental contact with the child seriously endangers or violates the child's well-being, it is important to find a difference between educational processes and "mistreatment". The literature indicates that maltreatment is manifested by all forms of physical and mental violence, harm, neglect, and exploitation including sexual exploitation. ${ }^{13}$

In this respect, it should be pointed out that the reason for a ruling prohibiting a child's contact with his or her parents should primarily be confirmed "mistreatment". Therefore, the thesis according to which upbringing standards do not fall within the scope of the analyzed legal regulation seems justified. Why are the parties so eager to fight with each other using accusations of children's "maltreatment"?

A conflict between parents often extends to embrace third parties, e.g. a cohabitant or cohabitee. In literature on the subject, the issue of a ban on contact between a cohabiting partner and a child of former spouses is extremely rarely raised. ${ }^{14}$ However, analyzing the content of a dozen or so quasi-consultation websites, it should be noted that this problem is becoming more and more common every year. Entering the phrase "prohibition of contact between a child and a new partner" into an Internet search engine, we can find at least a dozen or so questions on Internet forums or questions to practitioners. The answers are neither clear nor uniform. A legal problem herein is the legal basis of such a claim and justification of the thesis implying that a specific third party is a threat to the child's well-being. Not belittling the problem, the most common justification used here is the allegation that this third party is a home-wrecker or indecent person. The subject literature indicates that a legal basis for a possible claim for a ban on contact of a minor child with a third party being a cohabitant or cohabitee may be the above mentioned Article $113^{3}$ in connection with Article $113^{6}$ of K.r.i.o., or Article 109 of K.r.i.o., where the legislator states

12 W. Stojanowska, Rozwód a dobro dziecka, Warszawa 1979, p. 27.

13 E. Holewińska-Łapińska, Orzeczenie zakazu kontaktów z dzieckiem, Warszawa 2018, p. 12.

14 More: E. Holewińska-Łapińska, Kontakty z dziećmi innych osób niż ich rodzice (art. 1136 k.r.o.), Warszawa 2017; T. Justyński, Prawo do kontaktów z dzieckiem w prawie polskim i obcym, Warszawa 2011. 
that these provisions apply respectively to contacts of siblings, grandparents, relatives in a straight line as well as other persons if they have been taking care of the child for a long time. ${ }^{15}$ Consequently, legal regulations concerning contacts with a child may be applied analogously to a cohabitant or cohabitee. However, such a concept would still need to be duly justified in terms of protecting the best interests of the child. ${ }^{16}$ It is also worth mentioning in this respect the decision of the Supreme Court of 10 May 2000, III CKN 845/00, ${ }^{17}$ where the Supreme Court states that

the child's relatives (including grandparents) have no right to personal contact with the child (grandchild) under Polish family law. However, based on Art. 109 of the K.r.i.o., the guardianship court may, however, prohibit parents from unjustifiably hindering the child's contacts with their relatives and regulate the manner of maintaining them, as well as, if such contacts disrupt proper standards of the child's upbringing, prohibit personal contacts of the relatives with the child.

Leaving aside the question of factual circumstances of "mistreatment", arguments expressed by Irena Kurlak thereon appear to be correct. In her opinion, misfortunes experienced by the parties such as failure in their family life can have a fundamental impact on the way in which their further relations are formed, in particular those with children, but also with new partners of former spouses. ${ }^{18}$ Similarly, Alina Dobosz-Sztuba points out that "a reconstructed family strives for the same thing, but the ballast of the recent past, associated with the loss of a loved one and failure, may obscure the vision of the partner's needs" ${ }^{19}$

Following on from the second author, it should be noted that a so-called "patchwork family" has recently become quite popular as a category of family construction. Determining family relations in patchwork families is as difficult as determining their legal status. Members of reconstructed

15 J. Gajda, K. Pietrzykowski, in: Kodeks..., Art. $113^{6}$, Nb 1-2.

${ }_{16}$ M. Gąska, Więź rodzinna - refleksje nad charakterem dobra oraz dopuszczalnościa i sposobami kompensacji krzywdy wywołanej jego naruszeniem, Forum Prawnicze 2018, no. 1 (45), p. 19-34.

17 Legalis no. 278532.

18 I. Kurlak, Blaski i cienie powtórnego zamążójścia (Andragogiczno-feministyczne aspekty rekonstrukcji matżeństwa), Forum Pedagogiczne 2012, no. 1, p. 136.

19 A. Dobosz-Sztuba, Typy i cechy rodziny zrekonstruowanej, Problemy Rodziny 1989, no. 1, p. 21. 
families experience many phenomena and relationships that do not concern, e.g. nuclear families. In patchwork families, children often feel belonging to more than one family, it is difficult for them to find themselves during holidays and family celebrations, and have problems with assimilation and often do not feel part of such a family. The roles of stepmothers and stepfathers are problematic as they have no definite social roles, but at the same time there are many negative stereotypes about them. Everyone in childhood has learned the stories of Cinderella or Snow White and the Seven Dwarfs. Since our earliest years we have been accustomed, as a society, to a negative image of someone replacing one of our parents, especially our mother. Stepfathers do not have it any easier, although popular literature was more gracious to them. The characteristic features of reconstructed families that distinguish them from nuclear families according to Alina Dobosz-Sztuba's research are: ${ }^{20}$

1) Members of a reconstituted family have usually lost a loved one through death or through the breakdown of a marriage. This traumatizing fact affects them very strongly and may hinder the proper establishment of new intra-family relationships.

2) In a reconstructed family, one of the child's parents is dead or divorced and lives separately, and often has a new family. Therefore, each child in a reconstructed family has only one biological parent with him/her. The separated biological parent retains co-responsibility for the upbringing of his or her child, even though a greater range of caring and upbringing activities are performed on a daily basis by the adoptive parent.

3) Membership of a reconstituted family is not clearly defined, either because of biological ties or because of legal regulations. Hence, children from reconstructed families are members of more than one family community - they have, for example, three pairs (or four) of grandmothers and grandparents.

4) The legal positions of both parents are asymmetrically distributed. The foster parent does not have parental rights to the child of his or her partner. The children and their adoptive siblings are not related.

5) In addition to the roles of biological ties, in a reconstructed family there are acquired roles for which there are no clearly defined,

${ }^{20}$ Ibidem, p. 23-24. 
unambiguous social models. These are the roles of stepmother and stepfather.

6) The reconstructed family is generally not accepted by members of indigenous families because both divorce and new marriage usually meet with their disapproval.

7) The members of a reconstituted family do not have any history, they have to create it together.

Analyzing the individual points, it seems that the root of a problem arising in children's contacts with a parent's new partner are primarily emotions accompanying both children and parents. On the one hand, there is often a regret that it has not been possible to maintain the marriage, on the other hand, there is often a sudden desire to make a new acquaintance and to re-establish life quickly. These reactions sometimes do not keep up with children's emotions. In addition, the older children get, the more thoughts they have, which are much more difficult to calm down when these turn into emotions. Therefore, even a spark of mutual antipathy can leave a ruin in any relationship between a child and a parent's new partner. ${ }^{21}$

However, returning to the legal problem analyzed on the basis of this material, in ten out of the five analyzed cases, one of the parties demanded a ban on the other's contact with the minor child or children in the presence of third parties - cohabitees. In four divorce cases the third party was a female cohabiting partner, in one - a male cohabiting partner. The main reasons for such requests was the feeling of anger at the partner for leaving the family, establishing a relationship with a younger person, or becoming pregnant with a third party. It was pointed out that the good of the child was violated by demoralizing behavior involving "breaking the relationship up", making it impossible for the child to function in a full family, taking away one of the parents, etc. None of these arguments concerned the good of the child directly or indicated a direct threat or violation of their good. What is more interesting, in two out of the five cases, the children liked this new person. However, when asked by the psychologist, they stated that they should not like him/her.

The research material collected from these ten analyzed cases confirms that one of the most serious problems in establishing parental authority

21 See. W. Stojanowska, Rozwód a ochrona rodziny i dziecka - wybrane zagadnienia, Rodzina i Prawo 2008, no. 1-2 (7-8), p. 5-16. 
and arranging visitation rights are unstable emotions. It is understandable that parties apply for a ban on contact whenever there is a real concern that such contact could threaten the welfare and safety of the child. However, experience with such motions leads to a growing conviction that in cases where the good of the child is protected as the highest good, it is pushed into the category of means to an end.

\section{Conclusion}

Divorce cases have their specificity, involving both the delicate subject matters of the proceedings and their participants. During such proceedings, the parties repeatedly testify to things they would never have confessed to in their married life. It happens that it is only in a courtroom that spouses find out what they did not like about the relationship. It is difficult to find an answer to issues related to emotions. In divorce cases, the most difficult issue involves the legal as well as the actual situation of underage children. ${ }^{22}$ The ideal solution would be if, despite their parents' divorce, children could maintain a correct and systematic relationship with both (provided, of course, that the relationship was appropriate). However, this issue is most often approached by women from the following position: "my child, my problem". This is probably related to the strength of the maternal bond. Then, it is fully understandable and it may lead to an agreement. It is worse if it manifests itself in a form of a rebellion against the break-up of a marriage and a desire for revenge. Unfortunately, there are also accusations made by husbands that the mother has never been a good mother because she could not cook or clean the house. There can be many arguments and emotional baggage. In such difficult relationships, it has recently been more and more common for a marriage to break down because of a third person. This, unfortunately, further intensifies already complex emotions. This is precisely when divorcees most often file applications for a ban on making contact in the presence of third parties, or more precisely a specific third party. After all, it is not all of them, but this one person. From a legal point of view, such a claim may be resolved

22 See. E. Naumann, Rozwód w prawie polskim, Dziecko Krzywdzone. Teoria. Badania. Praktyka 2008, no. 25, p. 6-14. 
on the basis of existing regulations of family and guardianship law. In each case, however, such a ban must result from the need to protect child's well-being. Such situations happen extremely rarely, and in these ten divorce cases analyzed herein - they occurred in none. At the same time, it seems that the good of a child, which should by all means be protected, is used primarily to incriminate a former spouse, and to make it difficult for them to shape their relationship with the child. ${ }^{23}$ It seems, therefore, that the research thesis put forward at the beginning has been confirmed by the research conducted. Referring to the case-law of the European Court of Human Rights, it should be stressed that "the mutual enjoyment of time spent together by a parent and a child is an essential element of «family life» within the meaning of Article 8 of the Convention for the Protection of Human Rights and Fundamental Freedoms of 4 November 1950".${ }^{24}$ Returning to childhood literature, one can recall an extremely important sentence: "Love is not about looking at each other, but about looking together in the same direction". ${ }^{25}$ If we are no longer able to look at ourselves, let us look to the future of those who will always be there and for whom we are responsible.

\section{Bibliography}

Badowska-Hodyr M., Rodzice i ich dzieci w przestrzeni penitencjarnej z perspektywy zasady indywidualizacji oraz procesu reintegracji społecznej, Probacja 2018, no 1.

Bucińska J., Rodzina w świetle prawa międzynarodowego, in: Meritum. Prawo rodzinne, ed. G. Jędrejek, Warszawa 2017.

23 See. B. Czech, Z rozważań nad postępowaniem i orzecznictwem w sprawach rodzinnych (niezawisłość sędziowska, sprawy o rozwód, sprawy opiekuńcze matoletnich, sędziowie rodzinni, dobro dziecka, opinie biegłych), Rodzina i Prawo 2012, no. 20-21, p. 5-32.

24 More: Judgment of the European Court of Human Rights of 21.07.2015, 63777/09, Legalis no. 1378908; Judgment of the European Court of Human Rights of 16.09.2014, 2210/12, Legalis no. 1069691, Judgment of the European Court of Human Rights of 10.06.2014, 43123/10, Legalis no. 1069522; Judgment of the European Court of Human Rights of 15.04.2014, 17254/11, 1069441

25 A. de Saint-Exupéry, Ziemia, planeta ludzi, Wrocław 2017, ebook (rozdział 8, podrozdział 3). 
Czech B., Z rozważań nad postępowaniem i orzecznictwem w sprawach rodzinnych (niezawistość sędziowska, sprawy o rozwód, sprawy opiekuńcze małoletnich, sędziowie rodzinni, dobro dziecka, opinie biegtych), Rodzina i Prawo 2012, no. 20-21.

Ćwikowski R., Udziat dzieci w mediacji okołorozwodowej w Polsce $i$ wybranych państwach zachodnich, Probacja 2018, no. 1.

Czerederecka A., Rozwód a rywalizacja o opiekę nad dziećmi, Warszawa 2020.

Długoszewska J., Przestanki oraz skutki ograniczenia i pozbawienia władzy rodzicielskiej, Warszawa 2012.

Dobosz-Sztuba A., Typy i cechy rodziny zrekonstruowanej, Problemy Rodziny 1989, no. 1.

Domański M., Powierzenie wykonywania władzy rodzicielskiej jednemu z rodziców w wyroku rozwodowym, Prawo w Działaniu. Sprawy Cywilne 2015, vol. 21.

Gajda J., Pietrzykowski K., Kodeks Rodzinny i Opiekuńczy. Komentarz, Warszawa 2020, [database Legalis].

Gałkan-Halicka A., Władza rodzicielska a rozwód, in: Wokót problematyki małżeństwa w aspekcie materialnym i procesowym, eds. J.M. Łukasiewicz, A. M. Arkuszewska, A. Kościółek, Toruń 2017.

Gąska M., Więź rodzinna - refleksje nad charakterem dobra oraz dopuszczalnościa i sposobami kompensacji krzywdy wywołanej jego naruszeniem, Forum Prawnicze 2018, no 1 (45).

Główny Urząd Statystyczny, Rocznik Demograficzny 2019, Warszawa 2019.

Holewińska-Łapińska E., Kontakty z dziećmi innychosóbniż ich rodzice (art.1136 k.r.o.), Warszawa 2017.

Holewińska-Łapińska E., Orzeczenie zakazu kontaktów z dzieckiem, Warszawa 2018.

Justyński T., Prawo do kontaktów z dzieckiem w prawie polskim i obcym, Warszawa 2011.

Kiliańska A., Ograniczenie władzy rodzicielskiej, Przegląd Prawno-Ekonomiczny 2012, no. 18.

Kroczek P., Rodzina w polskim systemie prawnym we wspótczesnych okolicznościach życia, in: T. Borutka, T. Kornecki, P. Kroczek, Rodzina fundamentem społeczeństwa. Aspekt spoteczno-prawny, Kraków 2017.

Kurlak I., Blaski i cienie powtórnego zamążójścia (Andragogiczno-feministyczne aspekty rekonstrukcji matżeństwa), Forum Pedagogiczne 2012, no. 1.

Łolik M., Więź rodzinna jako dobro osobiste. Glosa do wyroku SN z dnia 10 lutego 2017 r., V CSK 291/16, Przegląd Sądowy 2018, no. 5.

Mostowik P., Kontakty dziecka z rodzicami, krewnymi i bliskimi a władza rodzicielska, Przegląd Sądowy 2013, no. 3.

Naumann E., Rozwód w prawie polskim, Dziecko Krzywdzone. Teoria. Badania. Praktyka 2008, no. 25.

Pachała E., Prawo do ochrony życia rodzinnego w świetle orzecznictwa Trybunału Konstytucyjnego, Przegląd Prawniczy UW 2018, vol. 17, no. 1. 
Pałka P., Ustalenie sposobu kontaktowania się z dzieckiem w toku postępowania o rozwód, Przegląd Sądowy 2006, no. 2.

de Saint-Exupéry A., Maty Książę.

Słyk J., Rozstrzyganie o istotnych sprawach dziecka w przypadku braku porozumienia rodziców (art. 97 § 2 k.r.o.), Prawo w Działaniu. Sprawy Cywilne 2013, no. 14.

Stojanowska W., Rozwód a dobro dziecka, Warszawa 1979.

Stojanowska W., Rozwód a ochrona rodziny i dziecka - wybrane zagadnienia, Rodzina i Prawo 2008, no. 1-2 (7-8).

Szaro M., Rodzina a poczucie sensu życia u osadzonych, Przegląd Więziennictwa Polskiego 2018, no. 98.

Tylec G., Zadośćuczynienie za naruszenie dobra osobistego w postaci więzi rodzinnej. Uwagi na tle orzecznictwa Europejskiego Trybunatu Praw Człowieka oraz orzecznictwa sądów polskich, Przegląd Sądowy 2018, no 3.

\section{Sum mary}

It seems that the institution of marriage is experiencing a crisis of trust. As a consequence of the lack of agreement between spouses, the welfare of underage children is suffering. Instead of being the center of attention, they become a part of a marital or post-marital skirmish. The purpose of this publication is to depict the legal situation of minor children in the exercise of parental authority, with particular emphasis on the exercise of contacts with parents. An additional objective is to draw attention to the fact that the child, whose welfare should be a priority in any proceedings, is repeatedly violated, first and foremost by those responsible for his or her protection, namely the parents. According to the research thesis put forward herein, a minor child of the parties to divorce proceedings becomes an element of the procedural game both for the duration of such proceedings as well as later - until the child reaches majority.

Key words: family, child, divorce, cohabitation, contacts, parental authority

\section{ZAKAZ WYKONYWANIA KONTAKTÓW Z MAŁOLETNIM DZIECKIEM W OBECNOŚCI OSÓB TRZECICH. ROZWAŻANIA NA PODSTAWIE SPRAW SĄDOWYCH Z ZAKRESU PRAWA RODZINNEGO}

\section{Streszczenie}

Wydaje się, że instytucja małżeństwa przeżywa kryzys zaufania. W konsekwencji braku porozumienia pomiędzy małżonkami cierpi dobro małoletnich dzieci. To 
one, zamiast pozostać w centrum uwagi, stają się częścią potyczki małżeńskiej lub postmałżeńskiej. Celem niniejszej publikacji jest wskazanie sytuacji prawnej małoletnich dzieci w wykonywaniu władzy rodzicielskiej, ze szczególnym uwzględnieniem wykonywania kontaktów z rodzicami. Za cel dodatkowy stawia się konieczność zwrócenia uwagi na fakt, że dziecko, którego dobro powinno być priorytetem każdego postępowania, wielokrotnie jest naruszane, przede wszystkim przez osoby odpowiedzialne w pierwszej kolejności za jego ochronę, czyli rodziców. Stawiana jest teza badawcza, zgodnie z treścią której małoletnie dziecko stron postępowania rozwodowego staje się elementem gry procesowej zarówno na czas trwania takiego postępowania, jak i w późniejszym czasie - do osiągnięcia pełnoletności.

Słowa kluczowe: rodzina, dziecko, rozwód, konkubent, kontakty, władza rodzicielska

\section{ЗАПРЕТ НА ОСУЩЕСТВЛЕНИЕ КОНТАКТОВ С НЕСОВЕРШЕННОЛЕТНИМ РЕБЕНКОМ В ПРИСУТСТВИИ ТРЕТЬИХ ЛИЦ. СООБРАЖЕНИЯ НА ОСНОВЕ СУДЕБНЫХ ДЕЛ ИЗ ОБЛАСТИ СЕМЕЙНОГО ПРАВА}

\section{Резюме}

Похоже, институт брака переживает кризис доверия. Вследствие разногласий между супругами страдает благо несовершеннолетних детей. Вместо того, чтобы оставаться в центре внимания, они становятся участниками супружеской или послебрачной борьбы. Цель данной публикации - показать правовое положение несовершеннолетних детей при осуществлении родительских прав, уделяя особое внимание контактам с их родителями. Дополнительной целью является необходимость привлечь внимание к тому факту, что ребенок, благополучие которого должно быть приоритетным во всех судебных разбирательствах, неоднократно нарушается, в основном лицами, ответственными в первую очередь за его защиту, то есть родителями. Выдвигается исследовательский тезис, согласно которому несовершеннолетний ребенок сторон бракоразводного процесса становится элементом процессуальной игры как на время такого разбирательства, так и в дальнейшем - до достижения совершеннолетия.

Ключевые слова: семья, ребенок, развод, сожитель, контакты, родительская власть 